Hydrol. Earth Syst. Sci., 14, 1081-1091, 2010

www.hydrol-earth-syst-sci.net/14/1081/2010/

doi: 10.5194/hess-14-1081-2010

(c) Author(s) 2010. CC Attribution 3.0 License.

\title{
Prospecting for safe (low fluoride) groundwater in the Eastern African Rift: the Arumeru District (Northern Tanzania)
}

\author{
G. Ghiglieri ${ }^{1}$, R. Balia ${ }^{2}$, G. Oggiano ${ }^{3}$, and D. Pittalis ${ }^{1}$ \\ ${ }^{1}$ Department of Territorial Engineering, Desertification Research Group (NRD), University of Sassari, Italy \\ ${ }^{2}$ Department of Territorial Engineering, University of Cagliari, Italy \\ ${ }^{3}$ Department of Botanical, Ecological and Geological Sciences, Desertification Research Group (NRD), \\ University of Sassari, Italy
}

Received: 21 October 2009 - Published in Hydrol. Earth Syst. Sci. Discuss.: 27 November 2009

Revised: 7 June 2010 - Accepted: 9 June 2010 - Published: 28 June 2010

\begin{abstract}
A multidisciplinary research effort, including geological, hydrogeological, hydro-chemical, geophysical and hydrological investigations, was aimed at locating a source of safe groundwater for a district of northern Tanzania, within the western branch of the East Africa Rift Valley, where water shortage is common and much of the surface water carries unacceptable levels of dissolved fluoride. The $440 \mathrm{~km}^{2}$ study area lies in the northern part of Arumeru district and is dominated by Mt. Meru ( $4565 \mathrm{~m}$ a.s.1.). The local climate is semi-arid, with distinct wet and dry seasons. Four hydrogeological complexes were identified, occurring within different volcanic formations, either alone or superimposed upon one another. The groundwater flow system was interpreted from the spatial distribution of the springs, combined with a lithology- and geometry-based reconstruction of the aquifers. The dominant pattern consists of a multi-directional flow from the higher elevations in the south towards the lower areas in the north, but this is complicated by structures such as grabens, faults, lava domes and tholoids. After the identification of the major fluoride source, an interference pattern between groundwater and high fluoride surface water was drawn. Finally, vertical electrical soundings were performed to define the location of aquifers in regions where release of fluoride was prevented. The methodological approach for the prospecting of safe water in a semi-arid, fluoride polluted region was validated by the drilling of a $60 \mathrm{~m}$ deep well capable of supplying at least $3.8 \mathrm{l} / \mathrm{s}$ of low fluoride, drinkable water.
\end{abstract}

Correspondence to: G. Ghiglieri (ghiglieri@uniss.it)

\section{Introduction}

Water shortage in the Ngarenanyuki and Oldonyosambu wards (Arumeru District, Northern Tanzania) restricts average per capita daily water consumption to eight litres, falling to 3-41 during the dry season. At this time, most of the population is compelled to concentrate around the few perennial water points. This level of consumption remains far below the Millennium Development Goal (MDG) objectives, which call for the provision of at least 201 per day per person by 2015 (United Nations, 2000). Serious problems are also associated with the quality of the water, much of which (both surface- and groundwater) has a high fluoride content, as a result of the alkaline volcanism which is widespread throughout the East Africa Rift System (Tekle-Haimanot et al., 2006; Jaroslav and Annukka, 2007). The fluoride level of the Rift System groundwater, however, does vary markedly from place to place (Tekle-Haimanot et al., 2006), depending on the influence exerted by local geology, and on climatic variation within the Rift Valley. It is generally accepted that fluoride build-up in groundwater results from a prolonged contact of the water with the rock (Banks et al., 1995; Gizaw, 1996; Frengstad et al., 2001; Carrillo-Rivera et al., 2002). Lithology is therefore an important determinant of groundwater fluoride concentration. Bedrock aquifers in alkaline magmatic rocks and metamorphic rocks are particularly associated with fluoride contaminated groundwater (Banks et al., 1995; Dowgiałło, 2000; Botha and van Rooy, 2001; Shanker et al., 2003); the minerals directly responsible for its release are fluorspar, fluorapatite, amphiboles (e.g. horneblende, tremolite) and certain micas.

Published by Copernicus Publications on behalf of the European Geosciences Union. 

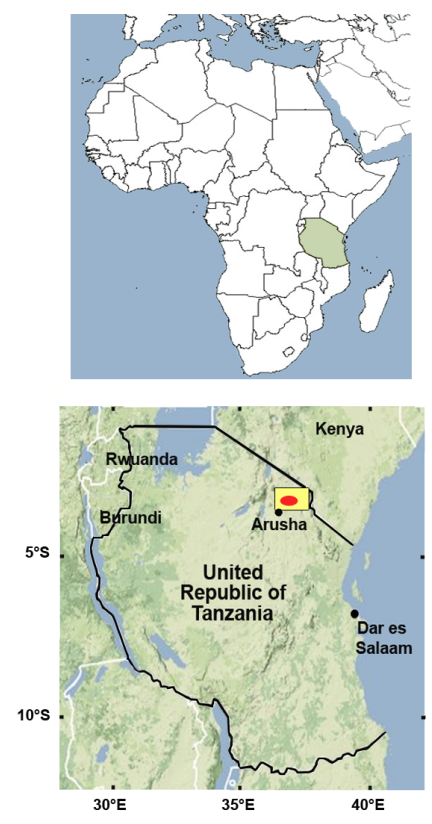

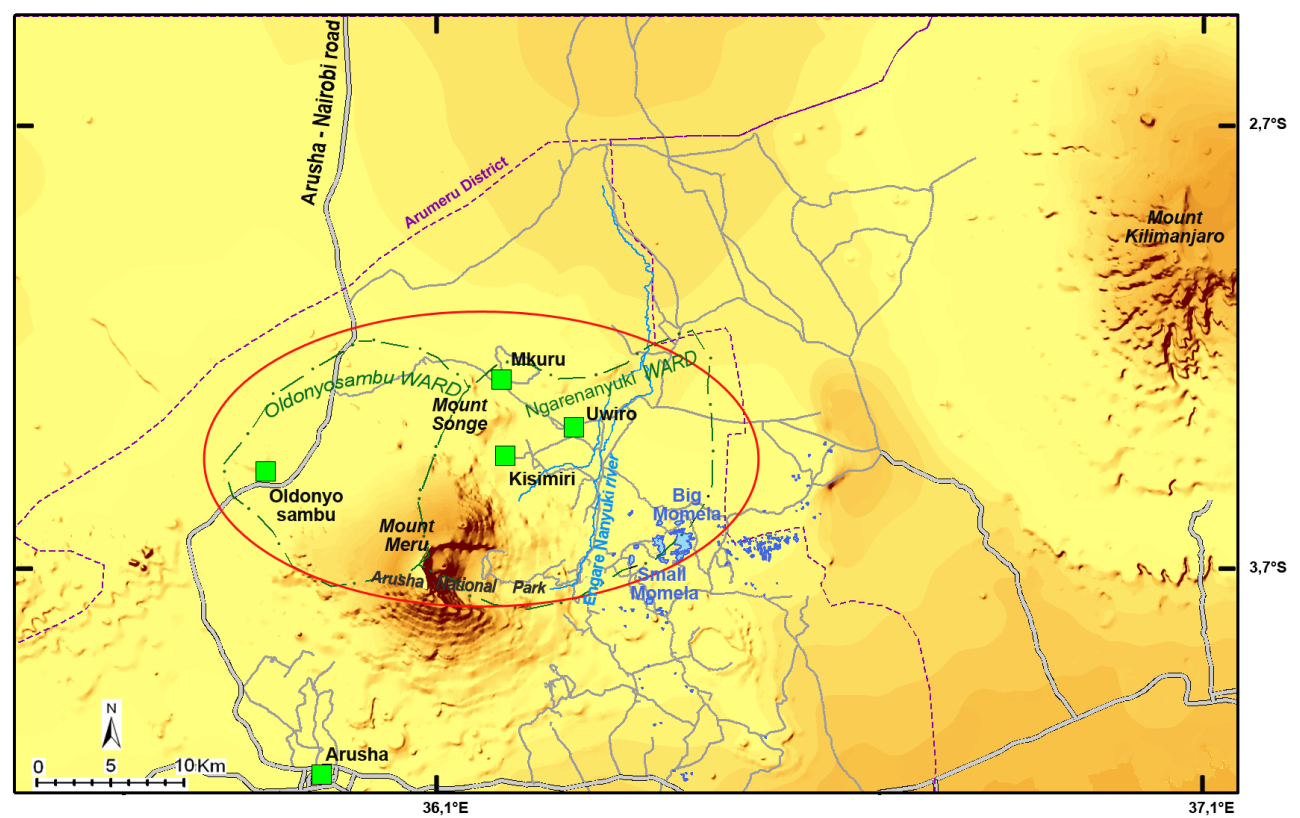

- Ward boundaries

- Study area

Fig. 1. Geographical map of the study area.

Since excessive consumption of fluoride can result in dental or skeletal fluorosis (Moller et al., 1970; Tekle-Haimanot et al., 2006), the consumption of fluoride-contaminated water in the Rift Valley has made these conditions commonplace throughout Ethiopia (Lester, 1974; Tekle Haimanot et al., 1987; Kloos and Tekle-Haimanot, 1999), Sudan (Smith et al., 1953) and Tanzania (Kilham and Hecky, 1973). Particularly high fluoride levels are found in the waters of Elementaita $(1640 \mathrm{mg} / \mathrm{l})$ and Nakuru $(2800 \mathrm{mg} / \mathrm{l})$ lakes in Kenya (Tekle-Haimanot et al., 2006). The World Health Organization suggested in 2006 an acceptable limit of $1.5 \mathrm{mg} / \mathrm{l}$ fluoride, but the Tanzanian government has been forced by an over-riding need to prevent water shortage, to raise this limit to $8 \mathrm{mg} / \mathrm{l}$. The urgent need to discover alternative sources of safe groundwater has prompted the present multidisciplinary study of a typical rural area located within a semi-arid microenvironment dominated by alkaline volcanic rocks. The aims of the study were to identify the main local source of fluoride, to locate aquifers unaffected by fluoride infiltration/release, and to develop strategies to exploit safe groundwater.

\section{Study area}

\subsection{Location, climatic and physiographic setting}

The project was sited in the $2966 \mathrm{~km}^{2}$ Arumeru district, Arusha region, northern Tanzania, lying to the west of Mt. Kilimanjaro, to the north of Mt. Meru, to the east of the Arusha to Nairobi (Kenya) road, and to the south of the Kenyan Amboseli National Park (Fig. 1). The district is administratively divided into six divisions, 37 wards and 133 villages. The $440 \mathrm{~km}^{2}$ project working area lies in the northern part of the district, around $50 \mathrm{~km}$ from Arusha, is bounded by Mt. Meru (4565 m a.s.l.) and the Arusha National Park, and includes nine villages in the Oldonyo Sambu and Ngarenanyuki wards. Three main ethnic groups present are the Wameru (mainly farmers) and the Waarusha and Maasai (mainly pastoralists). Despite its proximity to the equator, the study area has an Afro-Alpine semi-arid climate, characterized by two distinct seasons. The main wet season lasts from June to September and contributes $\sim 70 \%$ of the annual rainfall, while the minor wet season lasts from mid February to mid May. The remaining months are effectively dry, although occasional showers do occur during this period. The mean annual minimum and maximum temperatures are $20.6{ }^{\circ} \mathrm{C}$ and $28.5^{\circ} \mathrm{C}$, respectively, and the mean annual rainfall is $535.3 \mathrm{~mm}$ (AA.VV., 2000; Gea, 2005). As illustrated in Fig. 1, the topography of the area is dominated by the volcanic cone of Mt. Meru and its slopes cover most of the area. The remaining land is covered by alluvial fans fed from Mt. Meru. Recently active small volcanic cones are present in the north-western part of Mt. Meru, and a number of small maar-type flat craters are also present. The Big Momela and the Small Momela lakes, lying within Arusha National Park to the east of Mt. Meru, are saline and alkaline. The drainage pattern around Mt. Meru is radial, but further 

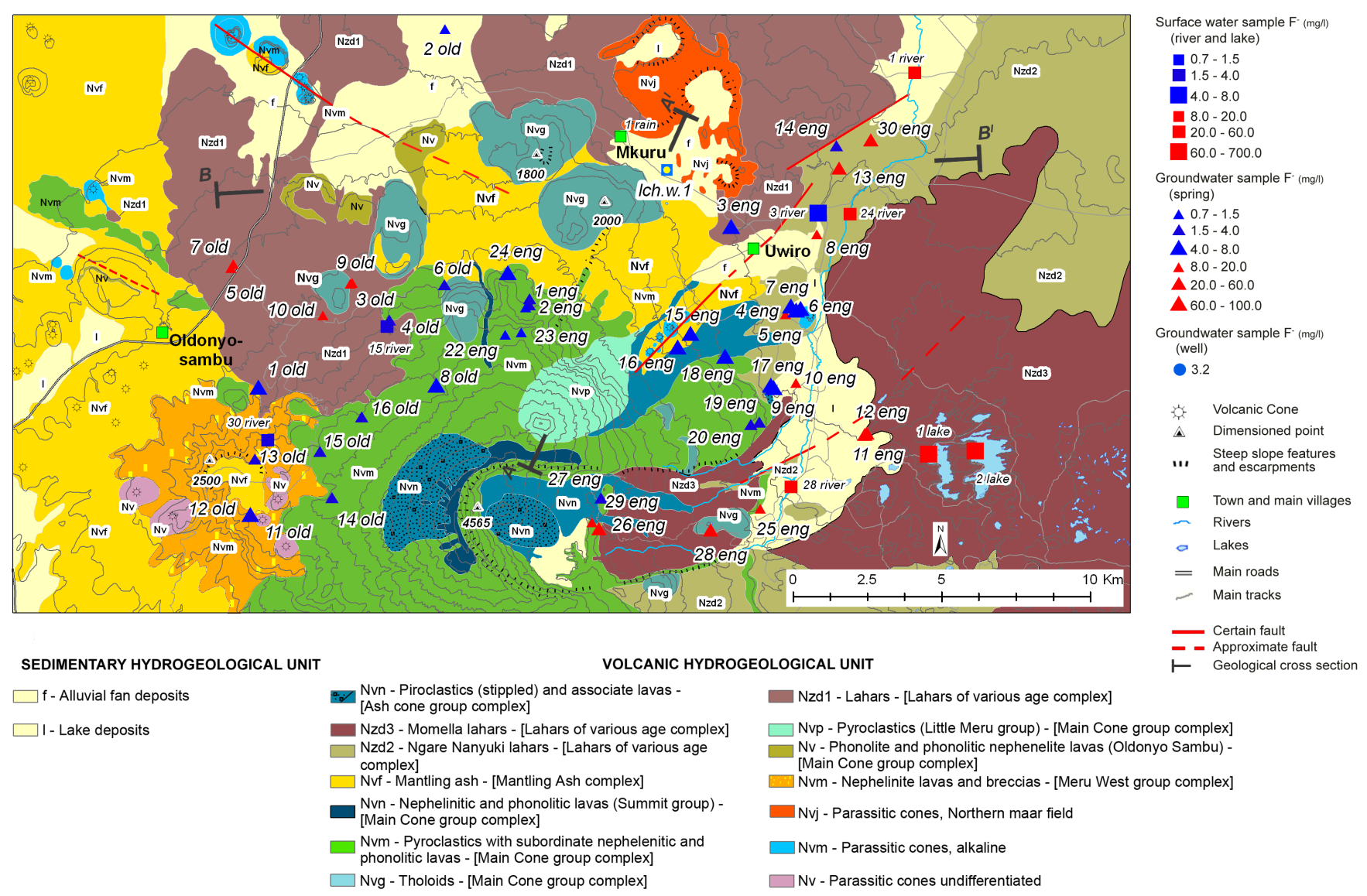

Fig. 2. Geological-hydrogeological map of the study area, indicating the location of water points.

down the slopes, many of the stream courses have been modified by tilting and capture. To the east and north-east of Mt. Meru, the only perennial stream is the Engare Nanyuki River, the waters of which have a high fluoride content, since they emerge from a spring yielding $\sim 5 \mathrm{l} / \mathrm{s}$ of water with a fluoride content of $60 \mathrm{ppm}$. This stream flows northwards into the inner Amboseli Basin and is used locally for irrigation purposes.

\subsection{Geological and hydrogeological setting}

The following general geological descriptions are based on the Geological Sheet "Arusha", Quarter Degree Sheet 55, 1983, scale 1:125000 - Geological Survey of Tanzania, while the hydrogeological setting is based on the current research activity.

The volcano-sedimentary sequences of the study area are Cenozoic; older ones date back to the Miocene-Pliocene, while the last recorded eruption occurred in the early 20th century. The lithology is dominated by volcanic rocks with some alluvial deposits (Fig. 2). No crystalline basement outcrops occur in the area, but they are present at shallow depths just a few kilometers to the north of the study area. Mt. Meru is considered as an active volcano with alkaline magmatic activity, typical within the East Africa Rift System. Its last documented eruption was in 1910, when it produced small emissions of black ash over a few days from the Ash Cone. As recently as 1954, a significant amount of fumarolic activity was recorded in the Ash Cone area, but by 1974 neither fumarolic activity nor anomalous soil temperatures remained detectable. Major rift faults are located in the north-western portion of the research area. Linear features and benches are common on the flanks of Mt. Meru, and it is highly probable that the early volcanic structure has been block-faulted. In the central area, the direction of the faults varies from north/south to north-north-east/south-south-west (Uwiro graben); in the north-western area, the trend is northwest/south-east (parasitic cone alignment). However, thick mantling ash and other younger formations hinder any precise mapping of faults. The age of this faulting lies between that of the flood lavas (2.3 My BP) and the parasitic cones (1.7 My BP), since some of the latter's lava covers the fault scarp. This dating ( 2.1 My BP) is consistent with the estimated age of other fault-phases (AA.VV., 1983).

The aquifer geometry, storage capacity, permeability, recharge areas, etc. of the study area have been assessed by combining the existing geological map (AA.VV., 1983) 
with fresh hydrogeological and geophysical surveys carried out in the frame of the present research. The main aquifer systems consist of volcanic formations, occurring singularly or superimposed upon one another. Subordinate perched aquifers (some previously localized) are present in some sedimentary formations. The thickness of the volcanic rocks is only approximately known because of uncertainties associated with the geological and geomorphological events which occurred during the Cenozoic era. However, it is clear that these events have heavily influenced the geometry of the aquifers, the recharge and discharge areas and the groundwater quality. The scale of the map and the amount of available data, however, prevents a detailed mapping of all these parameters. From a hydrogeological point of view, the lithostratigraphical formations can be grouped into two main hydrogeological units, namely a volcanic and a sedimentary unit (Fig. 2).

\subsubsection{Volcanic hydrogeologic unit}

This unit is divided into four hydrogeologic complexes:

- Meru west Group (Nvm);

- Lahars of various ages $\left(\operatorname{Nzd}_{1}\right)$, Ngare Nanyuki lahars $\left(\mathrm{Nzd}_{2}\right)$, Momella Lahar (Nzd3);

- Main cone group (Nvm), Ash cone group (Nvn);

- Mantling ash (Nvf);

\section{Meru west Group (Nvm) complex}

This formation belongs to the "older extrusive", and is exposed on the west side of Mt. Meru. The rocks consist predominantly of nephelinite lavas and breccias which contain dominant phonolite clasts. The aquifer hosted in this formation has fractured permeability.

\section{Lahars of various age $\left(\mathrm{Nzd}_{1}, \mathrm{Nzd}_{2}, \mathrm{Nzd}_{3}\right)$ complex}

From a hydrogeological point of view, the lahars can be grouped within a single complex. Lahars $\left(\mathrm{Nzd}_{1}\right)$ of considerable extension are commonly found interbedded with sedimentary sequences. These lahars are characterized by the presence of large and abundant boulders of feldsparphyric phonolite, with alkali feldspar phenocrysts occurring within a fine-grained matrix of variable hardness. $\mathrm{Nzd}_{2}$ and $\mathrm{Nzd}_{3}$ are exposed on the north-eastern and eastern slopes of the volcano, the former near Ngare Nanyuki and Uwiro graben, and the latter near the Momella lakes. The aquifers hosted in these rocks have double permeability, as they are both fractured and, to some extent, porous.

\section{Main cone group (Nvm) complex}

The Mt. Meru volcano was active from 0.20 to $0.08 \mathrm{My}$ BP. Volcanic activity extended the main cone to an alti- tude of at least $4877 \mathrm{~m}$ a.s.l., and perhaps was considerably higher at one time. The Main Cone group (Nvm) and Little Mt. Meru group (Nvp) materials are predominantly volcanic breccias and tuffs of many grain sizes, but phonolitic and nephelinitic (Nv) lavas are sporadically intercalated. The aquifer hosted in these rocks has double permeability (fractured and porous). The elevation difference between the recharge and discharge areas allows for the infiltration of rain water, particularly where the permeability is high (intensive fracturing). Along with a considerable number of high-yielding springs, this structure is responsible for the groundwater having a particularly short residence time. A further feature of the Main Cone group is the common occurrence of viscous domes or tholoids ( $\mathrm{Nvg}$ ), usually of feldsparphyric phonolite composition. These can occur at all levels, although there is a zone of especially large adventitious tholoids on the northern flanks (i.e. Mt. Songe). The occurrence of domes constitutes a lateral hydrogeological impermeable limit, which limits the circulation of groundwater.

\section{Mantling ash (Nvf) complex}

Thick ash, pumice and tuff deposits overlie large areas of the foothills of Mt. Meru, especially on its western slopes. In the study area, there are outcrops near Oldonyo Sambu and Kisimiri (north of Mt. Meru). This formation, due to its finegrained nature and clay alteration, is practically impermeable, so no springs emerge from it. Sometimes the complex underlies or surrounds an aquifer.

\subsubsection{Sedimentary hydrogeologic unit}

This unit is made up of fine-grained alluvial and lacustrine sediments, and hence is characterized by a low transmissivity. The occurrence of these sediments generates a swampy flatland crossed by the Engare Nanyuki River, which terminates towards the west in an area scattered with alkaline lakes. A perched, low productivity aquifer occurs in this formation - of the few springs present, most have only a poor yield.

\section{Materials and methods}

\subsection{Hydrogeological surveys}

The hydrogeological survey, which was extended beyond the limits of the two study wards, identified and catalogued 52 water points and 46 springs (30 in the Ngarenanyuki ward and 16 in Oldonyosambu), and included six surface water samples (rivers and lakes). For each water point, the following parameters were recorded: elevation, geographical coordinates (GPS), $\mathrm{pH}$, electrical conductivity, temperature, fluoride content, yield (estimated values), hydrogeological characteristics and spring classification (Tables 1 and 2). Each water point was identified by an alphanumeric code. The in 


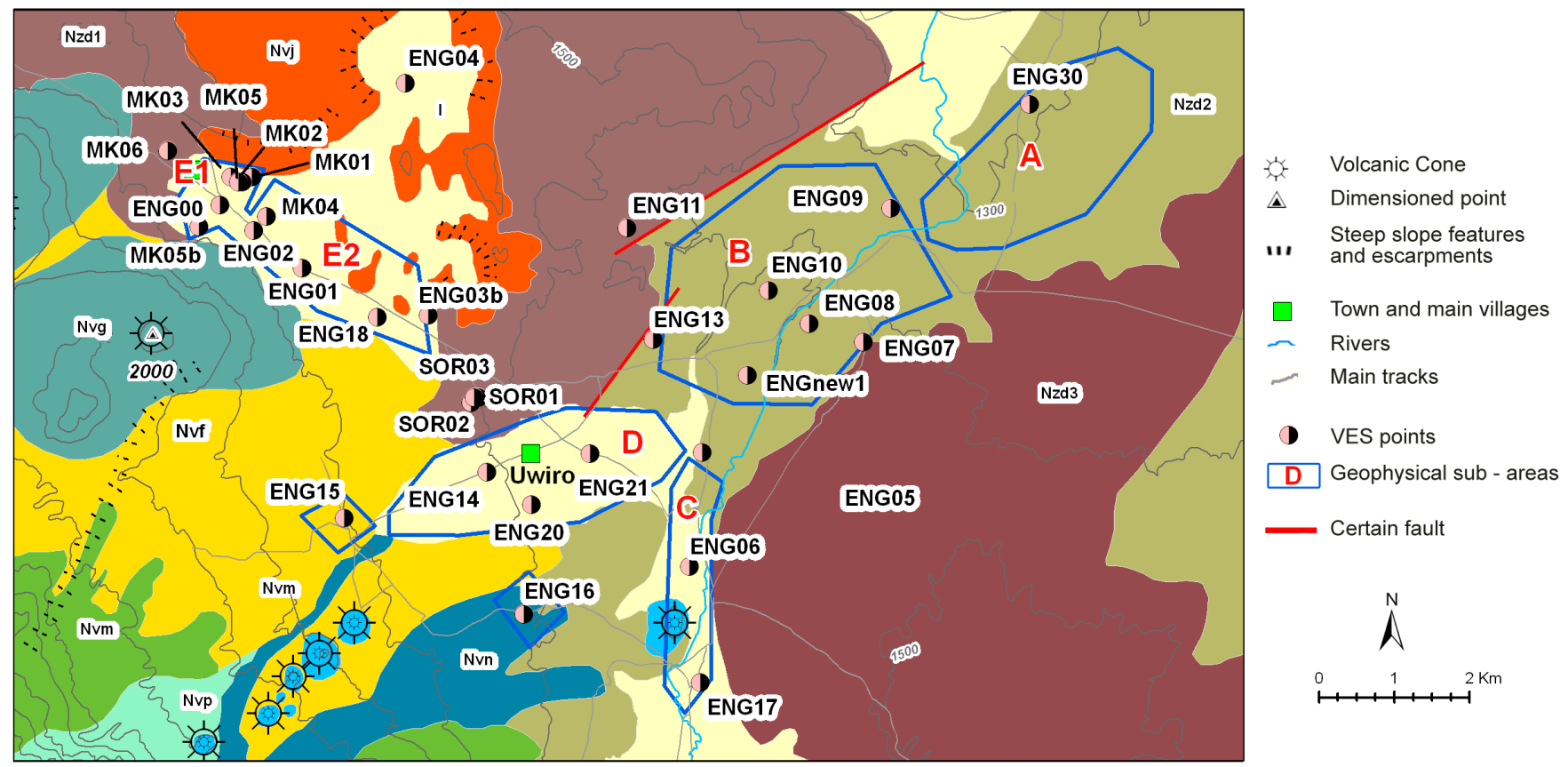

Fig. 3. Location map of the electrical soundings in the Ngarenanyuki ward. Sub-areas defined as explained in Table 3. For the geological legend, see Fig. 2.

situ analysis of the groundwater samples included fluoride content, $\mathrm{pH}$, electrical conductivity and temperature. Fluoride were measured using a Fluoride LR Photometer (Hanna Instrument $\mathrm{HI}$ 93739), while the temperature, $\mathrm{pH}$ and electrical conductivity at $25^{\circ} \mathrm{C}$ were measured using a portable $\mathrm{pH}-$ conductivity meter (HI 98130 HANNA Instruments). Readings were taken at various times during the dry and wet seasons. For each water point, the data were entered into a digital database and GIS, using ArcGIS v9.2 and the open source software gvSIG. The location of each water point was plotted to allow a view of the distribution of all parameters, in particular the fluoride content (Fig. 2).

\subsection{Geophysical surveys}

The geophysical survey was confined to the Ngarenanyuki and Oldonyosambu wards, and was intended to evaluate the local groundwater resources. Relevant data were acquired with a VES (Vertical Electrical Sounding) technique, using a Schlumberger electrode array and an ABEM Terrameter SAS 300. The resulting apparent resistivity curves were interpreted by a computer program based on the linear digital filtering method (Koefoed, 1972, 1979; O'Neill and Merrick, 1984). Current software packages based on this approach are able to cope with extreme apparent resistivity contrasts and to deal with a large number of layers. In all, 15 soundings were taken in the Oldonyosambu ward and 33 in the Ngarenanyuki ward. In the former, no clear signature of any exploitable groundwater could be inferred from the apparent resistivity curves, but in the Ngarenanyuki ward, it was possible to locate several potential sources of groundwater. The VES position map for the Ngarenanyiuki ward is shown in Fig. 3.

\section{Results}

The majority of the springs producing low fluoride content water (below the national standard for rural water) emerged from either basaltic or phonolitc unaltered lava, in the main located at high altitudes within the Mt. Meru Main Cone Group Complex, and - although to a lesser extent - along its northern lower slopes (Fig. 2 and Table 1). High fluoride content water emerged from lahars and lacustrine deposits. A notable exception to this general pattern was represented by spring 26 Eng (Fig. 2), sited within the Mt. Meru cone at $2502 \mathrm{~m}$ a.s.l. Given its water temperature $\left(22.4^{\circ} \mathrm{C}\right)$ and location, this spring is probably of hydrothermal origin; it feeds the Engare Nanyuky River at a rate of $61 / \mathrm{s}$, and its water contains $59-68 \mathrm{mg} / \mathrm{l}$ fluoride. As such, it represents a source of pollution to both the river and any dependent aquifers, particularly the area of structural low within the Uwiro graben, where some epiclastite-hosted aquifers are fed from the river. Epiclastite and proximal lahars are separated by paleosoils (Fig. 4) which are able to concentrate and then release fluoride thanks to the anion exchange capacity of both phillosilicates and zeolites, which are present as alteration products of the ash matrix. 
Table 1. Summary of springs attributes.

\begin{tabular}{|c|c|c|c|c|c|c|c|c|c|c|c|c|}
\hline $\begin{array}{l}\text { ID } \\
\text { Spring }\end{array}$ & $\begin{array}{l}\text { Collect } \\
\text { data }\end{array}$ & $\begin{array}{l}\text { UTM } \\
\text { East }\end{array}$ & $\begin{array}{l}\text { UTM } \\
\text { North }\end{array}$ & $\begin{array}{l}\text { Altitude } \\
\text { (m a.s.l.) }\end{array}$ & $\begin{array}{l}\text { Spring } \\
\text { type }\end{array}$ & Spring regimen & $\begin{array}{l}\text { Spring geologic } \\
\text { classification }\end{array}$ & $\begin{array}{l}\text { Discharge } \\
(1 / \mathrm{s})\end{array}$ & $\begin{array}{c}T \\
\left({ }^{\circ} \mathrm{C}\right)\end{array}$ & $\begin{array}{c}\text { Cond } \\
(\mathrm{mS} / \mathrm{cm})\end{array}$ & $\mathrm{pH}$ & $\begin{array}{c}F \\
(\mathrm{mg} / \mathrm{l})\end{array}$ \\
\hline $1 \mathrm{eng}$ & $18 \mathrm{Feb} 07$ & 252273 & 9648852 & 2249 & localized & catched, perennial & Fracture, Nvm & 0.15 & 18.0 & 0.64 & 7.4 & 3.0 \\
\hline 2 eng & $18 \mathrm{Feb} 07$ & 252156 & 9648544 & 2276 & localized & $\begin{array}{l}\text { catched down the valley, } \\
\text { perennial }\end{array}$ & Fracture, Nvm & N/A & 15.0 & 0.50 & 6.0 & 1.3 \\
\hline 3 eng & $21 \mathrm{Feb} 07$ & 259060 & 9651282 & 1500 & diffused & not catched, perennial & $\begin{array}{l}\text { Gravity, contact, } \\
\text { Nzd1 }\end{array}$ & N/A & 24.3 & 0.74 & 7.5 & 4.9 \\
\hline 4 eng & 7 Mar 07 & 261073 & 9648602 & 1453 & N/A & $\begin{array}{l}\text { catched in irrigation canal, } \\
\text { perennial }\end{array}$ & $\begin{array}{l}\text { Gravity, contact, } \\
\text { Nzd } 2\end{array}$ & N/A & 23.0 & 0.73 & 6.8 & 6.9 \\
\hline 5 eng & 7 Mar 07 & 261243 & 9648462 & 1454 & localized & $\begin{array}{l}\text { catched in irrigation canal, } \\
\text { perennial }\end{array}$ & $\begin{array}{l}\text { Gravity, contact, } \\
\text { Nzd2 }\end{array}$ & N/A & 23.4 & 0.63 & 6.7 & 5.4 \\
\hline 6 eng & 7 Mar 07 & 260888 & 9648316 & 1465 & N/A & not catched, perennial & N/A, Nzd2 & 0.80 & 23.4 & 1.02 & 6.9 & 10.5 \\
\hline 7 eng & 7 Mar 07 & 261397 & 9648526 & 1450 & localized & not catched, perennial & $\begin{array}{l}\text { Gravity, contact, } \\
\text { Nzd2 }\end{array}$ & 2.60 & 20.2 & 0.81 & 6.9 & 7.7 \\
\hline 8 eng & 8 Mar 07 & 261944 & 9651008 & 1422 & diffused & catched, perennial & Artesian, Nzd2 & N/A & 22.0 & 1.16 & 7.0 & 10.0 \\
\hline 9 eng & 8 Mar 07 & 260480 & 9645862 & 1495 & localized & not catched, perennial & $\begin{array}{l}\text { Gravity, contact, } \\
\text { Nvn }\end{array}$ & 0.80 & 19.0 & 0.54 & 6.4 & 5.0 \\
\hline 10 eng & 8 Mar 07 & 261243 & 9646006 & 1483 & localized & not catched, perennial & Artesian, Nzd1 & 0.03 & 23.0 & 1.53 & 7.6 & 19.1 \\
\hline 11 eng & 8 Mar 07 & 263619 & 9644238 & 1514 & diffused & $\begin{array}{l}\text { not catched, dry during dry- } \\
\text { season }\end{array}$ & $\begin{array}{l}\text { Artesian, con- } \\
\text { tact, Nzd1 }\end{array}$ & 0.05 & 22.0 & 1.86 & 8.3 & 25.4 \\
\hline 12 eng & 8 Mar 07 & 263553 & 9644286 & 1520 & localized & not catched, perennial & $\begin{array}{l}\text { Artesian, con- } \\
\text { tact, Nzd1 }\end{array}$ & 0.02 & 21.8 & 1.86 & 8.2 & 23.2 \\
\hline 13 eng & 7 Mar 07 & 262593 & 9653986 & 1350 & localized & $\begin{array}{l}\text { not catched, dry during dry- } \\
\text { season }\end{array}$ & Fracture, Nzd2 & 0.01 & 26.6 & 0.90 & 7.4 & 2.6 \\
\hline 14 eng & 12 Mar 07 & 262674 & 9653232 & 1389 & localized & $\begin{array}{l}\text { not catched, dry during dry- } \\
\text { season }\end{array}$ & N/A, Nzd2 & 0.04 & 24.4 & 4.30 & 8.3 & 44.0 \\
\hline 15 eng & 15 Mar 07 & 257259 & 9647224 & 1730 & localized & not catched, perennial & Contact, Nvn & 0.12 & 17.7 & 0.33 & 6.1 & 5.4 \\
\hline 16 eng & 15 Mar 07 & 257694 & 9647686 & 1640 & localized & catched, perennial & Contact, Nvn & 3.00 & 16.6 & 0.33 & 6.4 & 5.3 \\
\hline 17 eng & 18 Mar 07 & 260391 & 9645944 & 1500 & diffused & catched, perennial & Contact, Nvn & 5.00 & 18.5 & 0.56 & 6.1 & 5.1 \\
\hline 18 eng & 18 Mar 07 & 258847 & 9646904 & 1580 & localized & catched, perennial & $\begin{array}{l}\text { Contact, } \\
\text { Nvm/Nvn }\end{array}$ & 3.00 & 18.6 & 0.47 & 6.7 & 5.2 \\
\hline 19 eng & 20 Mar 07 & 259997 & 9644704 & 1650 & N/A & catched, perennial & N/A, Nvm & 2.00 & 17.5 & 0.40 & 7.3 & 3.5 \\
\hline 20 eng & 20 Mar 07 & 259715 & 9644614 & 1693 & diffused & catched, perennial & Fracture, Nvm & N/A & 15.5 & 0.40 & 6.4 & 3.6 \\
\hline 21 eng & 24 Mar 07 & 252258 & 9648646 & 2250 & localized & catched, perennial & Fracture, Nvm & 0.05 & 14.7 & 0.30 & 6.3 & 2.0 \\
\hline 22 eng & 24 Mar 07 & 251460 & 9647636 & 2660 & diffused & $\begin{array}{l}\text { catched down the valley, } \\
\text { perennial }\end{array}$ & Fracture, Nvm & 0.20 & 13.3 & 0.25 & 5.6 & 1.4 \\
\hline 23 eng & 24 Mar 07 & 252009 & 9647712 & 2654 & localized & $\begin{array}{l}\text { catch. in the korongo down } \\
\text { the valley exceptionally dry }\end{array}$ & Fracture, Nvm & 0.01 & 14.6 & 0.17 & 5.7 & 0.7 \\
\hline 24 eng & 24 Mar 07 & 251540 & 9649722 & 2236 & localized & catched, perennial & Fracture, Nvm & N/A & 18.5 & 1.08 & 7.1 & 7.1 \\
\hline 25 eng & 26 Mar 07 & 260045 & 9641778 & 1620 & localized & not catched, perennial & $\begin{array}{l}\text { Artesian, frac- } \\
\text { ture, Nvm }\end{array}$ & 3.00 & 20.2 & 1.51 & 6.0 & 10.0 \\
\hline 26 eng & 26 Mar 07 & 254609 & 9641105 & 2502 & localized & not catched, perennial & $\begin{array}{l}\text { Artesian, frac- } \\
\text { ture, Nzd3 }\end{array}$ & 6.00 & 20.4 & 4.82 & 7.8 & 60.0 \\
\hline 27 eng & 26 Mar 07 & 254682 & 9642148 & 2550 & localized & not catched, perennial & $\begin{array}{l}\text { Fracture, } \\
\text { Nvm/Nvn }\end{array}$ & 0.04 & 12.2 & 0.34 & 6.4 & 3.8 \\
\hline 28 eng & 26 Mar 07 & 258372 & 9641064 & 1969 & diffused & catched, perennial & N/A, Nzd3 & 4.00 & 16.6 & 1.44 & 7.4 & 28.2 \\
\hline 29 eng & 5 Apr 07 & 254378 & 9641318 & 2582 & localized & not more catched, perennial & $\begin{array}{l}\text { Contact, } \\
\text { Nvm/Nvn }\end{array}$ & 0.10 & 17.3 & 1.39 & 7.8 & 20.0 \\
\hline 30 eng & 22 Apr 07 & 263749 & 9654174 & 1337 & localized & not catched, perennial & N/A, Nzd2 & 0.20 & 24.8 & 3.74 & 8.1 & 31.0 \\
\hline 1 old & 19 Feb 07 & 243163 & 9645872 & 2119 & N/A & catched, perennial & N/A, Nvm2 & 6.00 & 20.4 & 0.70 & 8.2 & 4.3 \\
\hline 2 old & $21 \mathrm{Feb} 07$ & 249443 & 9657902 & 1470 & N/A & $\begin{array}{l}\text { not catched, dry during dry- } \\
\text { season }\end{array}$ & $\begin{array}{l}\text { Shallow dug- } \\
\text { well, alluvial } \\
\text { fan deposits }\end{array}$ & N/A & 30.0 & 0.40 & 7.0 & 0.9 \\
\hline 3 old & $21 \mathrm{Feb} 07$ & 246328 & 9649372 & 2095 & localized & catched, perennial & $\begin{array}{l}\text { Gravity, contact, } \\
\text { Nzd1 }\end{array}$ & 0.40 & 17.2 & 0.48 & 7.3 & 12.3 \\
\hline 4 old & $21 \mathrm{Feb} 07$ & 247564 & 9648126 & 2272 & localized & catched, perennial & N/A, Nvm & 1.00 & 16.6 & 0.53 & 7.6 & 2.5 \\
\hline 5 old & $22 \mathrm{Feb} 07$ & 242323 & 9650010 & 1800 & diffused & catched, perennial & Fracture, Nzd1 & 0.40 & 20.0 & 0.62 & 7.5 & 13.0 \\
\hline 6 old & 13 Mar 07 & 249420 & 9649314 & 2100 & localized & catched, perennial & Contact, Nvm & 0.50 & 14.0 & 0.64 & 6.0 & 2.5 \\
\hline 7 old & 13 Mar 07 & 242249 & 9649874 & 1800 & diffused & catched, perennial & Fracture, Nzd1 & 0.60 & 21.0 & 0.56 & 7.5 & 14.3 \\
\hline 8 old & 14 Mar 07 & 249148 & 9645944 & 2600 & localized & catched, perennial & Fracture, Nvm & 3.50 & 11.5 & 0.20 & 7.2 & 4.6 \\
\hline 9 old & 23 Mar 07 & 246262 & 9649347 & 2055 & localized & catched, perennial & $\begin{array}{l}\text { Gravity, contact, } \\
\text { Nzd1 }\end{array}$ & 2.50 & 13.9 & 0.51 & 7.3 & 14.7 \\
\hline 10 old & 23 Mar 07 & 245338 & 9648282 & 2099 & diffused & catched, perennial & N/A, Nzd1 & 2.00 & 15.4 & 0.50 & 7.3 & 17.6 \\
\hline 11 old & 27 Mar 07 & 242900 & 9641576 & 2515 & localized & catched, perennial & Contact, Nvm2 & 0.35 & 14.8 & 0.60 & 6.5 & 3.1 \\
\hline 12 old & 27 Mar 07 & 242899 & 9641592 & 2515 & localized & catched, perennial & Contact, Nvm2 & 0.20 & 14.7 & 0.49 & 6.5 & 4.1 \\
\hline 13 old & 27 Mar 07 & 243048 & 9643464 & 2479 & localized & $\begin{array}{l}\text { catched down the valley, } \\
\text { perennial }\end{array}$ & Fracture, Nvm2 & 0.80 & 14.6 & 0.63 & 7.5 & 4.0 \\
\hline 14 old & 27 Mar 07 & 245636 & 9642156 & 2841 & localized & catched, perennial & Fracture, Nvm & 0.01 & 12.9 & 0.63 & 6.4 & 2.9 \\
\hline 15 old & $2 \mathrm{Apr} 07$ & 245225 & 9643710 & 2616 & diffused & catched, perennial & Fracture, Nvm & 0.50 & 13.2 & 0.45 & 7.3 & 3.0 \\
\hline 16 old & 2 Apr 07 & 246635 & 9644878 & 2634 & N/A & catched, perennial & N/A, Nvm & 1.00 & 14.4 & 0.21 & 7.0 & 1.6 \\
\hline
\end{tabular}


Table 2. Summary of rivers attributes.

\begin{tabular}{ccccccccc}
\hline $\begin{array}{c}\text { ID } \\
\text { river/lake }\end{array}$ & $\begin{array}{c}\text { Collect } \\
\text { data }\end{array}$ & $\begin{array}{c}\text { UTM } \\
\text { East }\end{array}$ & $\begin{array}{c}\text { UTM } \\
\text { North }\end{array}$ & $\begin{array}{c}\text { Altitude } \\
(\mathrm{m} \text { a.s.1. })\end{array}$ & $\begin{array}{c}T \\
\left({ }^{\circ} \mathrm{C}\right)\end{array}$ & $\begin{array}{c}\text { Cond } \\
(\mathrm{mS} / \mathrm{cm})\end{array}$ & pH & $\begin{array}{c}F \\
(\mathrm{mg} / \mathrm{l})\end{array}$ \\
\hline 1 River & 7 Mar 07 & 265220 & 9656432 & 1282 & 26.6 & 1.08 & 8.5 & 28.0 \\
2 River & 12 Mar 07 & 262671 & 9653238 & 1386 & 23.2 & 1.67 & 8.2 & 14.0 \\
3 River & 12 Mar 07 & 261987 & 9651728 & 1417 & 22.8 & 1.21 & 7.6 & 6.2 \\
4 River & 12 Mar 07 & 260664 & 9651158 & 1456 & 24.5 & 0.96 & 7.2 & 5.4 \\
15 River & 14 Mar 07 & 247450 & 9647930 & 2280 & 19.0 & 0.43 & 7.3 & 1.9 \\
29 River & 22 Mar 07 & 261137 & 9642677 & 1572 & 19.1 & 2.07 & 8.5 & 22.8 \\
21 River & 21 Mar 07 & 261297 & 9647032 & 1469 & 25.4 & 1.89 & 8.1 & 13.0 \\
23 River & 19 Mar 07 & 262096 & 9649314 & 1441 & 23.6 & 2.06 & 8.4 & 26.2 \\
24 River & 19 Mar 07 & 263053 & 9651684 & 1405 & 25.0 & 2.40 & 8.8 & 26.8 \\
22 River & 19 Mar 07 & 261639 & 9647560 & 1455 & 23.3 & 1.74 & 8.4 & 23.2 \\
26 River & 22 Mar 07 & 261387 & 9643697 & 1537 & 20.4 & 1.78 & 8.4 & 29.4 \\
30 River & 21 Mar 07 & 243477 & 9644073 & 2467 & 14.6 & 7.80 & 0.6 & 3.1 \\
28 River & 26 Mar 07 & 261072 & 9642508 & 1583 & 17.9 & 2.12 & 8.5 & 28.0 \\
1 Lake & 23 Apr 07 & 265699 & 9643622 & 1440 & 26.1 & 7.10 & 9.8 & 149.1 \\
2 Lake & 23 Apr 07 & 267261 & 9643727 & 1440 & 25.8 & N/A & 10.3 & 528.0 \\
\hline
\end{tabular}

Most of the geophysical soundings inferred the presence of a low resistivity layer confined between two relatively high resistivity ones. Figure 5a shows four of the most promising apparent resistivity curves from the Ngarenanyuki ward, with their corresponding interpretation. The portion of the curve corresponding to the anomaly, which is interpreted as a confined or a semi-confined aquifer, appears as an ellipse, and the presumed aquifer layer is indicated by an arrow in the respective resistivity column obtained via the inversion process. The strong inference from these data was that in this particular sub-area, a thick layer associated with a confined or semi-confined aquifer was present at a depth of 20-36 m below the ground surface.

By way of comparison, the outcome of sounding ENG15 is shown in Fig. 5b; this shows overall low values, which are associated with clay-rich, largely saturated top soil, below which resistivity increases continuously and without any anomaly suggestive of the presence of a confined aquifer.

On the basis of the apparent resistivity curves and the geological and hydrogeological features, a number of homogeneous sub-areas were finally distinguished (marked by uppercase lettering in Fig. 3).

- Sub-area A: soundings ENG30 and ENG09, indicating the possible presence of groundwater at depths ranging from a few up to $35 \mathrm{~m}$ below ground level;

- Sub-area B: soundings ENG10, ENG08, ENG07, ENG13, ENGnew1 in the Uwiro graben. These exhibited a column with very low resistivity values (3$4 \mathrm{ohm} \mathrm{m}{ }^{-1}$ ) from the surface to a depth of at least $90 \mathrm{~m}$. This signature is highly indicative of the presence of groundwater, possibly at various levels in a multi-layer aquifer;

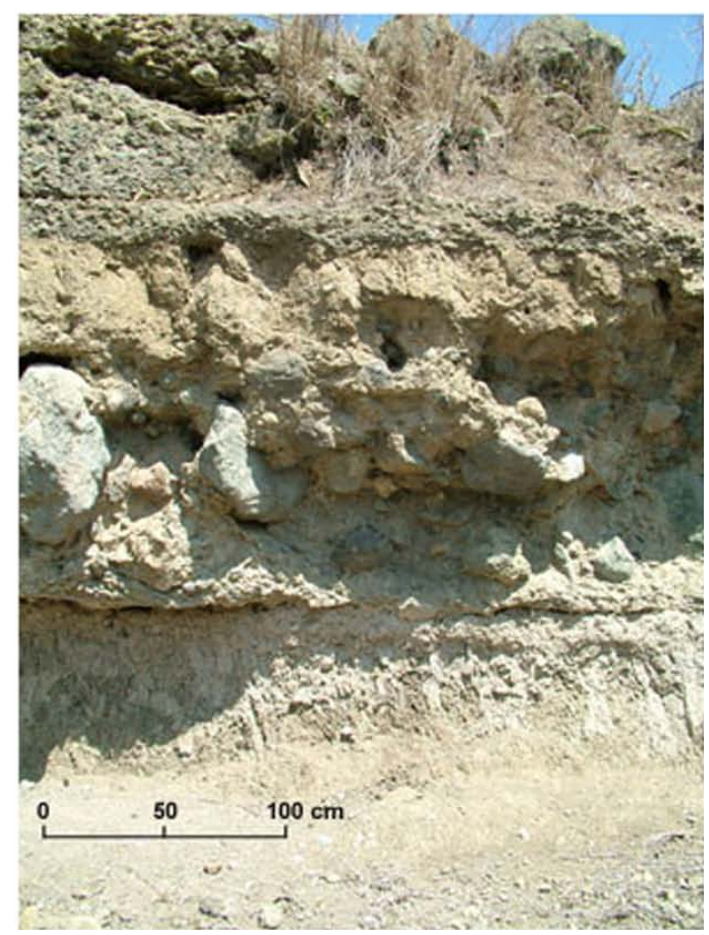

Fig. 4. Clayey level (paleosoil) between lahars and mantling ash.

- Sub-area C: soundings ENG05, ENG06, ENG17, which suggest that aquifers may be present at $30-60 \mathrm{~m}$ below the surface;

- Sub-area D: soundings ENG 14, ENG 20, ENG 21. Apart from the first few meters below the ground surface, these apparent resistivity curves were interpreted 

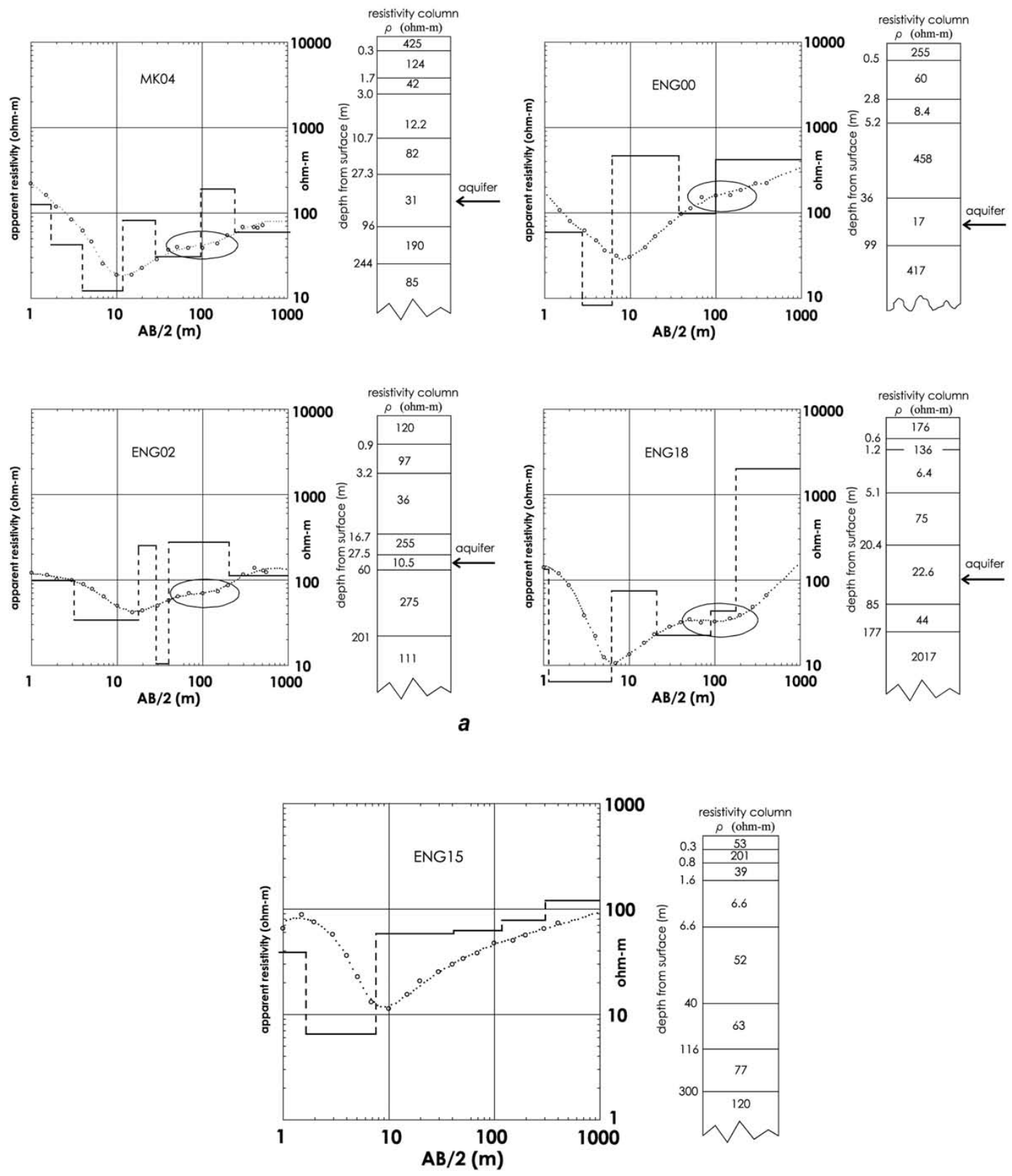

b

Fig. 5. (a) An apparent resistivity curve (left) and its inferred resistivity column (right). Small circles represent experimental values, and the dotted line the apparent resistivity curve corresponding to the resistivity column on the right. (b) Apparent resistivity curve and interpretation of VES ENG15. The resistivity column suggests that no confined aquifer is present.

in the same way as for sub-area C. However this area is rather distant from the Engare Nanyuki River and is crossed by several ephemeral streams emerging from the surrounding hills;

- Sub-area E1: soundings MK01, MK02, MK03, MK05 and MK05b, all of which were located in a structural high with respect to the Uwiro graben, so that no influx from the Engarenaniyuki River can be expected. The soundings indicated the presence of groundwater some $30 \mathrm{~m}$, and of further aquifers at $100-200 \mathrm{~m}$ below the surface;

- Sub-area E2: soundings ENG00, ENG01, ENG02, MK04, ENG18, ENG03b, which are the most promising in terms of the presence of groundwater. These indicate the presence of a conductive layer extending from few meters to $15 \mathrm{~m}$ below the surface, followed by a 


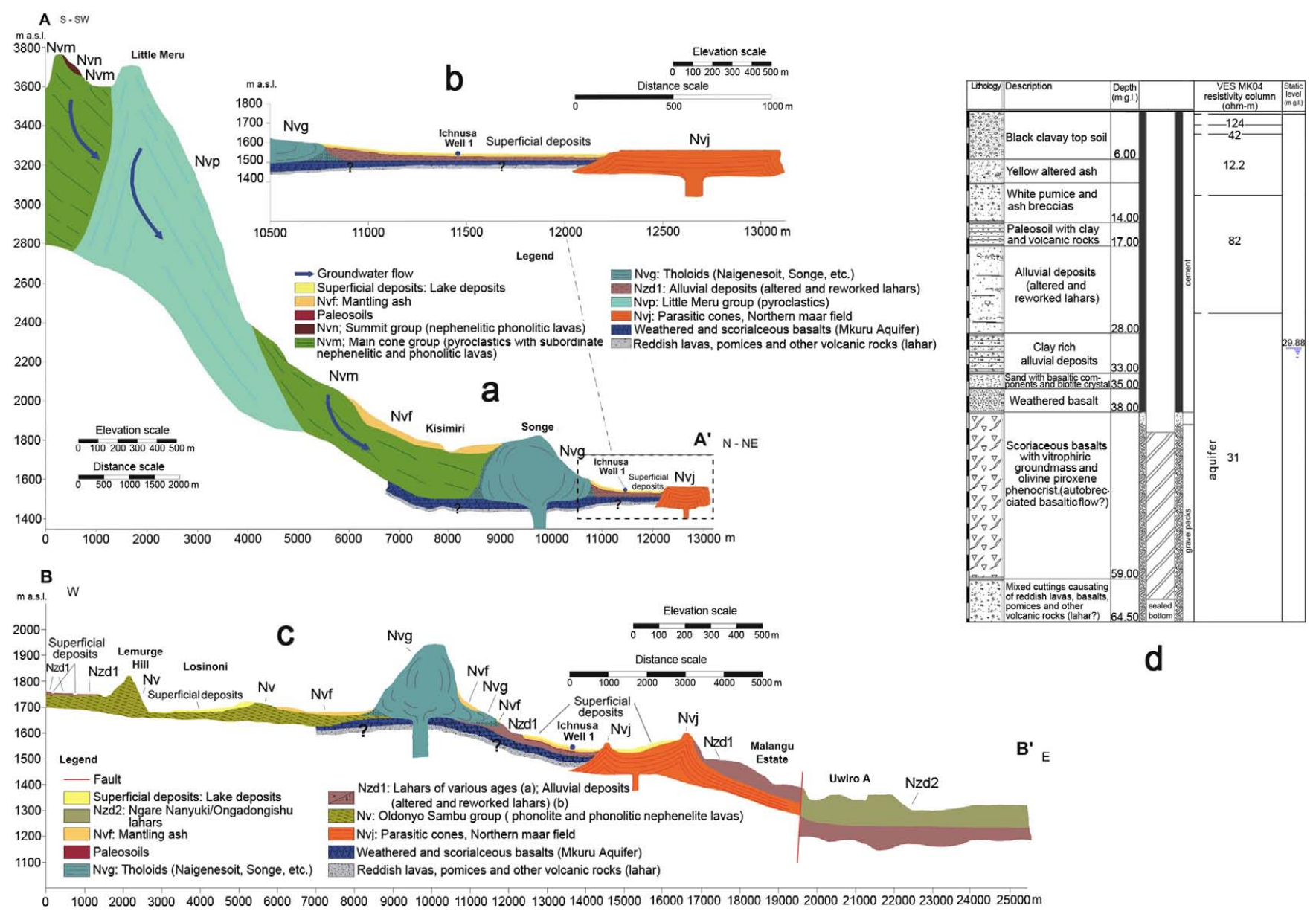

Fig. 6. (a) Geological-hydrogeological cross section $A-A^{\prime}$ (vertical magnification factor $\sim \times 4$ ). (b) Detail of the area surrounding the Ichnusa Well 1. (c) Geological-hydrogeological cross section B-B' (vertical magnification factor $\sim \times 7$ ). (d) The Ichnusa Well 1: lithological $\log$ and well construction report. This shows a comparison between the stratigraphy and the resistivity column of the electrical sounding MK04.

relatively resistive layer, and then a second conductive layer starting at $36 \mathrm{~m}$ below the surface. This second potential aquifer has a thickness ranging from 40 to $150 \mathrm{~m}$.

\section{Prospecting strategy}

The low fluoride content spring waters emerged by and large from unaltered phonolitic, basaltic, and pyroclastic volcanic rocks, mostly from the high elevation zone of Mt. Meru. The two most likely explanations for this observation are firstly that these waters do not remain in extended contact with the rock, and secondly that alteration products (such as paleosoils), while common in the lahars, are largely absent. No calcrete or lacustrine salty deposits with salty soils and scooped magadi (Nielsen, 1999) occur in this area. All these readily leachable products rather are found in the Uwiro graben and elsewhere in the lower lying and flatter land away from the volcano itself. The predicted location of sources of groundwater is summarized in Table 3.

The table indicates whether accessing an aquifer is likely to be productive, but does not imply anything regarding the quality of the water within the aquifer. Indications of water quality can be inferred from geological and hydrogeological considerations. Since the fluoride content of the water emerging from lahars and from the superficial lacustrine sediments is $>10 \mathrm{ppm}$ (and up to $68 \mathrm{ppm}$ ), the aquifers of the entire area between Uwiro graben and Momela Lakes are likely to be of poor quality. This area is also crossed by the only perennial river of the district, which is fed by at least one hydrothermal spring (26 Eng) delivering up to $34 \mathrm{ppm}$ of its water fluoride content. Thus sub-areas A through D are unsuitable for exploitation, as their aquifers are most probably over-contaminated with fluoride. Conversely, the high altitude area to the north-west of the fault zone, marked by the cones aligned to the north-north-east (Fig. 2), is not only independent for its water on the Engare Nanyuki River, but also 
Table 3. Operative synthesis of the survey results. Columns 3 and 4 show, respectively, drilling suitability and a suggested maximum drilling depth. The former is scaled from $0-5$, where " 0 " = do not drill at all, and "5" = area particularly suitable for drilling. The sub-areas in the second column are shown in Fig. 3.

\begin{tabular}{lccc}
\hline Ward & Sub-area & $\begin{array}{c}\text { Drilling } \\
\text { suitability } \\
(0-5)\end{array}$ & $\begin{array}{c}\text { Maximum } \\
\text { drilling } \\
\text { depth }(\mathrm{m})\end{array}$ \\
\hline Ngarenanyuki & A & 1 & 40 \\
& B & 2 & 100 \\
& C & 1 & 80 \\
& D & 3 & 80 \\
& E1 & 2 & 50 \\
& E2 & 5 & 100 \\
\hline
\end{tabular}

exhibits many outcrops of basalt lava flow originating from the relatively old $\mathrm{NVj}$ volcanic suite, capable of forming a productive and non-polluted groundwater reservoir. Thus we focussed on sub-area E2 as a best fit between the needs of the local Maasai settlement and the hydrogeological conditions predicted to produce safe water in a borehole.

\subsection{The borehole}

The drilling operation, lithological log (drill cuttings were collected every $1 \mathrm{~m}$ ), well design, well completion and pumping test were carried out by the Water Solutions Drilling Company in January 2008. During the drilling, the water was sampled for the measurement of chemical-physical parameters and fluoride content. The borehole (named Ichnusa Well 1) is illustrated in Figs. 2 and 6. The drilling provided a detailed stratigraphy of the Mkuru area, and in particular, uncovered a buried scoriaceous, autobrecciated basalt formation at $38-59 \mathrm{~m}$ below ground level, hosting a confined aquifer with high permeability. A pumping test (drawdown log-time test) was carried out over the period 18-20 January 2008 to estimate transmissivity and storativity. Available equipment limited the pumping rate to $3.81 / \mathrm{s}$ from $60 \mathrm{~m}$ below ground level, so it was not possible to estimate the maximum pumping rate, or to evaluate the well efficiency by means of a Step Drawdown test. At the above pumping rate, the maximum drawdown was just $45 \mathrm{~cm}$, which is too weak to allow a steep drawdown test. The relationship between drawdown and time was evaluated from a $48 \mathrm{~h}$ period of pumping at $3.8 \mathrm{l} / \mathrm{s}$. The Theis method pumping test gave a transmissivity of $9.12 \times 10^{-3} \mathrm{~m}^{2} / \mathrm{s}$ and a storativity value of $6.30 \times 10^{-2}$. No barrier boundary or recharge effect was experienced during this test, confirming that the maximum pumping rate of the Ichnusa Well 1 is $>3.81 / \mathrm{s}$. In situ analyses of fluoride content showed a constant level of $3.1 \mathrm{mg} / \mathrm{l}$, which is lower than elsewhere in the study area, and well below the national limit.

\section{Conclusions}

Both shallow and deep circulating groundwater are present in the volcanic district surrounding the northern slopes of Mt. Meru. The former occurs in perched aquifers in unconsolidated or semi-unconsolidated sediments and is rather scarce. These aquifers are of limited extent, and are largely restricted to sandy river beds and superficial paleo-lake sedimentary deposits. Both intermediate and deep groundwater circulation systems where the permeability of the aquifer and the elevation difference between the recharge and the discharge areas encourages relatively deep infiltration are present. The deepest infiltration occurs where brittle rock has been fractured or faulted over a wide area. In these cases, a large recharge area, in conjunction with substantial rainfall, can generate productive wells and springs (e.g. in the Main cone group complex Nvm).

The groundwater regional flow system is in general determined by the landform, and is dominated by flow from the higher elevation areas in the south towards the lower areas in the north. Recharge is achieved by a combination of direct infiltration (rainfall), infiltration of run-off water, and via lateral systems in which groundwater is exchanged between distinct hydrogeological units. The second of these sources is characteristic of volcanic uplands, especially where there is variation in the steepness of the slope. Lateral exchange is implicated in the Mkuru area, where an aquifer present in weathered and scoriaceous basalts at a depth of $40-60 \mathrm{~m}$ is fed by the groundwater, infiltrating from a high elevation area within the main cone group and Tholoid phonolites.

Fractured or autobrecciated lava-flow aquifers are associated with a low release of fluoride, either because of their high transmissivity (which reduce the residence time of groundwater), and/or because weathering-derived products or salty deposits are largely absent. The Engare Nanyuki River, fed mainly by the fluoride-rich hydrothermal spring 26 Eng, contributes to the pollution of the aquifers which are hydraulically connected to it in the lowland within the Uwiro graben. Geo-structural and hydrogeological data over the entire study area cannot provide sufficient data to define the water balance necessary for estimating run-off, actual infiltration or groundwater recharge.

Clearly, the present data set provides a basis for planning interventions aimed at improving access to unpolluted water. We have been able to evaluate, for various sub-areas, whether the water shortage problem would be better addressed by providing more drilled wells, or by improving the springs catchment, or by a combination of both of these measures. However, such interventions cannot be planned purely on the base of technical results, since social and economical factors must also be taken into consideration. The development plans already approved by the local Authorities, in conjunction with the expectations of local people, are the proper drivers for any subsequent research. 
Acknowledgements. This research was carried out as part of a project funded by OIKOS Institute (Italy), the Charity and Defence of Nature Fund (private foundation) and the Sardinia local Government (Italy) (Regional Law 19/96: cooperation with developing countries). Thanks are also due to Fondazione Banco di Sardegna for a grant of financial support to D. Pittalis, and to OIKOS EAST-AFRICA for offering technical and logistical support within Tanzania.

Edited by: A. D. Reeves

\section{References}

AA.VV.: Geological map: Arusha - Quarter Degree Sheet 55 scale 1:125.000 Geological Survey of Tanzania, 1983.

AA.VV.: Arusha Region water master plan, Final Report, United Republic of Tanzania, United Nation Development Programme, 2000.

Banks, D., Reimann, C., Røyset, O., Skarphagen, H., and Sæther, O. M.: Natural concentrations of major and trace elements in some Norwegian bedrock groundwaters. Appl. Geochem., 10, 1-16, 1995.

Botha, F. S. and Van Rooy, J. L.: Affordable water resource development in the northern province, South Africa, J. African Earth Sci., 33, 687-692, 2001.

Carrillo-Rivera, J. J., Cardona, A., and Edmunds, W. M.: Use of abstraction regime and knowledge of hydrogeological conditions to control high-fluoride concentration in abstracted groundwater: San Luis Potosí basin, Mexico, J. Hydrogeol., 261, 24-47, 2002.

Dowgiałło, J.: Thermal water prospecting results at Jelenia Go'raCieplice (Sudetes, Poland) versus geothermometric forecasts, Environ. Geol., 39, 433-436, 2000.

Frengstad, B., Banks, D., and Siewers, U.: The chemistry of Norwegian groundwaters: IV. The ependence of element concentrations in crystalline bedrock groundwaters, Sci. Total Environ., 277, 101-117, 2001.

Gea, F.: Analysis of issues connected with water supplying in Maasai pasturelands around the village of Uwiro (Arusha, Tanzania), Graduation Thesis University of Torino (Italy), 149 pp., 2005.

Gizaw, B.: The origin of high bicarbonate and fluoride concentration in waters of the Main Ethiopian Rift Valley, East African Rift system, J. Afr. Earth Sci., 22, 391-402, 1996.
Jaroslav, V. and Annukka, L.: Groundwater Resources Sustainability Indicators - Unesco, IAEA, IAH, United Nations Educational, Scientific and Cultural Organization, IHP/2007/GW, 14, 115 pp., 2007.

Kilham, P. and Hecky, R. E.: Fluoride: geochemical and ecological significance in East African waters and sediments, Limnol. Oceanogr., 18, 932-945, 1973.

Kloos, H. and Tekle-Haimanot, R.: Distribution of fluoride and fluorosis in Ethiopia and prospects for control, Tropical Medicine and International Health, 4, 355-364, 1999.

Koefoed, O.: A note on the linear filter method of interpreting resistivity sounding data, Geophysical Prospecting, 20, 403-405, 1972.

Koefoed, O.: Geosounding Principles, 1: Resistivity Sounding Measurements. Elsevier Science Publ. Co. Inc., 1979.

Lester F.: Fluoride myelopathy, with a review of literature, Ethiop. Med. J., 12, 39-49, 1974.

Moller, I. J., Pindborg, J. J., Gedalia, I., and Roed-Peterson, B.: The prevalence of dental fluorosis in the people of Uganda, Arch. Oral Biol., 15, 213-55, 1970.

Nielsen, J. M.: East African magadi (trona): fluoride concentration and mineralogical composition, J. African Earth Sci., 29, 423428, 1999.

O’Neill, D. J. and Merrick, N. P.: A digital linear filter for resistivity sounding with a generalized electrode array, Geophys. Prospecting, 32, 105-123, 1984.

Shanker, R., Thussu, J. L., Prasad, J. M.: Geothermal studies at Tattapani hot spring area, Sarguja district, central India, Geothermics, 16, 61-76, 2003.

Smith, D. A., Harris, H. A., and Kirk, R.: Fluorosis in the Butan, Sudan, J. Trop. Med. Hyg., 8, 57-80, 1953.

Tekle-Haimanot, R., Fekadu, A., and Bushra, B.: Endemic fluorosis in the Ethiopian Rift Valley, Trop. Geogr. Med., 39, 209-217, 1987.

Tekle-Haimanot, R., Melaku, Z., Kloos, H., Reimann, C., Fantaye, W., Zerihun, L., and Bjorvatn, K.: The geographic distribution of fluoride in surface and groundwater in Ethiopia with an emphasis on the Rift Valley, Sci. Total Environ., 367, 182-190, 2006.

United Nation: United Nation Millennium Declaration, United Nation General Assembly, A/RES/55/2, United Nation, New York, 2000.

WHO: Guidelines for drinking-water quality, First addendum to third edition, Vol.1 - Recommendations, 595 pp. 2006. 